\title{
The ACER pollen and charcoal database: a global resource to document vegetation and fire response to abrupt climate changes during the last glacial period
}

María Fernanda Sánchez Goñi ${ }^{1,2}$, Stéphanie Desprat ${ }^{1,2}$, Anne-Laure Daniau ${ }^{3}$, Frank C. Bassinot ${ }^{4}$, Josué M. Polanco-Martínez ${ }^{2,5}$, Sandy P. Harrison ${ }^{6,7}$, Judy R. M. Allen ${ }^{8}$, R. Scott Anderson ${ }^{9}$, Hermann Behling ${ }^{10}$, Raymonde Bonnefille ${ }^{11}$, Francesc Burjachs ${ }^{12}$, José S. Carrión ${ }^{13}$,

Rachid Cheddadi ${ }^{14}$, James S. Clark ${ }^{15}$, Nathalie Combourieu-Nebout ${ }^{16}$, Colin. J. Courtney Mustaphi ${ }^{17}$, Georg H. Debusk ${ }^{18}$, Lydie M. Dupont ${ }^{19}$, Jemma M. Finch ${ }^{20}$, William J. Fletcher ${ }^{21}$, Marco Giardini $^{22}$, Catalina González ${ }^{23}$, William D. Gosling ${ }^{24}$, Laurie D. Grigg ${ }^{25}$, Eric C. Grimm ${ }^{26}$, Ryoma Hayashi ${ }^{27}$, Karin Helmens ${ }^{28}$, Linda E. Heusser ${ }^{29}$, Trevor Hill ${ }^{20}$, Geoffrey Hope ${ }^{30}$, Brian Huntley ${ }^{8}$, Yaeko Igarashi ${ }^{31}$, Tomohisa Irino $^{32}$, Bonnie Jacobs ${ }^{33}$, Gonzalo Jiménez-Moreno ${ }^{34}$, Sayuri Kawai ${ }^{35}$, A. Peter Kershaw ${ }^{36}$, Fujio Kumon ${ }^{37}$, Ian T. Lawson ${ }^{38}$, Marie-Pierre Ledru ${ }^{14}$, Anne-Marie Lézine ${ }^{39}$, Ping Mei Liew ${ }^{40}$,

Donatella Magri $^{22}$, Robert Marchant ${ }^{17}$, Vasiliki Margari ${ }^{41}$, Francis E. Mayle ${ }^{42}$, G. Merna McKenzie ${ }^{36}$, Patrick Moss $^{43}$, Stefanie Müller ${ }^{44}$, Ulrich C. Müller ${ }^{45}$, Filipa Naughton ${ }^{46,47}$, Rewi M. Newnham ${ }^{48}$, Tadamichi Oba ${ }^{49}$, Ramón Pérez-Obiol ${ }^{50}$, Roberta Pini ${ }^{51}$, Cesare Ravazzi ${ }^{51}$, Katy H. Roucoux ${ }^{38}$, Stephen M. Rucina ${ }^{52}$, Louis Scott ${ }^{53}$, Hikaru Takahara ${ }^{54}$, Polichronis C. Tzedakis ${ }^{41}$, Dunia H. Urrego ${ }^{55}$, Bas van Geel ${ }^{56}$, B. Guido Valencia ${ }^{57}$, Marcus J. Vandergoes ${ }^{58}$, Annie Vincens ${ }^{11}$, Cathy L. Whitlock ${ }^{59}$, Debra A. Willard ${ }^{60}$, and Masanobu Yamamoto ${ }^{49}$

${ }^{1}$ EPHE, PSL Research University, 33615 Pessac, France

${ }^{2}$ Université de Bordeaux, EPOC, UMR 5805, 33615 Pessac, France

${ }^{3}$ CNRS, Université de Bordeaux, EPOC, UMR 5805, 33615 Pessac, France

${ }^{4}$ Laboratoire des Sciences du Climat et de l'Environnement, LSCE/IPSL, CEA-CNRS-UVSQ, Université

Paris-Saclay, 91191 Gif-sur-Yvette, France

${ }^{5}$ Basque Centre for Climate Change - BC3, 48940 Leioa, Spain

${ }^{6}$ Department of Biological Sciences, Macquarie University, North Ryde NSW 2109, Australia

${ }^{7}$ School of Archaeology, Geography and Environmental Sciences (SAGES), Reading University, Whiteknights, Reading, RG6 6AB, UK

${ }^{8}$ Department of Biosciences, Durham University, South Road, Durham, DH1 3LE, UK

${ }^{9}$ Environmental Programs, School of Earth Sciences and Environmental Sustainability, Northern Arizona University, Flagstaff, AZ 86011, USA

${ }^{10}$ Department of Palynology and Climate Dynamics, Albrecht von Haller Institute for Plant Sciences, University of Göttingen, 37073 Göttingen, Germany

${ }^{11}$ CEREGE (UMR 6635), Aix-Marseille Université CNRS, IRD, Collège de France, Europole de l'Arbois, BP80, 13545 Aix-en-Provence, France

${ }^{12}$ ICREA Barcelona, Catalonia, Spain, Institut Català de Paleoecologia Humana i Evolució Social, Campus Sescelades URV, W3, 43007 Tarragona, Spain

${ }^{13}$ Departamento de Biología Vegetal, Facultad de Biología, Universidad de Murcia, 30100 Murcia, Spain

${ }^{14}$ Institut des Sciences de l'Evolution de Montpellier, UMR 5554 Université Montpellier 2, Bat.22, CC061,

Place Eugène Bataillon, 34095 Montpellier CEDEX 5, France

${ }^{15}$ Duke Trinity College of Art and Sciences, Durham, NC 27708, USA

${ }^{16}$ UMR 7194 CNRS, Histoire naturelle de l'Homme Préhistorique, Département de Préhistoire, Muséum national d'Histoire naturelle, 75013 Paris, France

${ }^{17}$ The York Institute for Tropical Ecosystem Dynamics (KITE), Environment Department, University of York, York, Heslington, YO10 5DD, UK 
${ }^{18}$ Department of Zoology, Duke University, Box 90325, Durham, NC 27708-0325, USA

${ }^{19}$ MARUM - Center for Marine Environmental Sciences, University of Bremen, 28359 Bremen, Germany

${ }^{20}$ Discipline of Geography, School of Agricultural, Earth and Environmental Sciences, University of KwaZulu-Natal, Pietermaritzburg, South Africa

${ }^{21}$ Quaternary Environments and Geoarchaeology, Geography, School of Environment and Development, University of Manchester, Oxford Road, Manchester, M13 9PL, UK

${ }^{22}$ Dipartimento di Biologia Ambientale, Sapienza Università di Roma, 1303 Rome, Italy

${ }^{23}$ Departamento de Ciencias Biológicas, Universidad de los Andes, A.A. 4976 Bogotá, Colombia

${ }^{24}$ Department of Ecosystems \& Landscape Ecology, University of Amsterdam, 1090 GE Amsterdam, the Netherlands

${ }^{25}$ Geology and Environmental Science Department, Norwich University, Northfield, VT 05663, USA

${ }^{26}$ University of Minnesota, Department of Earth Sciences, Minneapolis, MN 55455, USA

${ }^{27}$ Lake Biwa Museum, Oroshimocho1091, Kusatsu 525-0001, Japan

${ }^{28}$ Department of Physical Geography and the Bolin Centre for Climate Research, Stockholm University, Stockholm, Sweden

${ }^{29}$ Lamont-Doherty Earth Observatory of Columbia University, Palisades, NY 10601, USA

${ }^{30}$ Department of Archaeology and Natural History, The Australian National University, Fellows Road, Acton ACT 0200, Australia

${ }^{31}$ Institute for Paleoenvironment of Northern Regions, Koyocho 3-7-5, Kitahiroshima 061-1134, Japan

${ }^{32}$ Geological Institute, University of Tokyo, Hongo, Bunkyo-ku, Tokyo 113-0033, Japan

${ }^{33}$ Roy M. Huffington Department of Earth Sciences, Southern Methodist University, Dallas, TX 75275-0395, USA

${ }^{34}$ Departamento de Estratigrafía y Paleontología, Universidad de Granada, 18071 Granada, Spain

${ }^{35}$ Institute of Mountain Science, Shinshu University, Asahi 3-1-1, Matsumoto 390-8621, Japan

${ }^{36}$ School of Earth, Atmosphere and Environment, Monash University, Melbourne, VIC 3800, Australia

${ }^{37}$ Department of Environmental Sciences, Faculty of Science, Shinshu University, Asahi 3-1-1, Matsumoto 390-8621, Japan

${ }^{38}$ Department of Geography and Sustainable Development, University of St Andrews, St Andrews, KY16 9AL, UK

${ }^{39}$ LOCEAN - Laboratoire d'Océanographie et du Climat: Expérimentations et Approches Numériques, UPMC, 75252 Paris, France

${ }^{40}$ Department of Geosciences, National Taiwan University, 1, Sec. 4, Roosevelt Rd., Taipei 106, Taiwan, ROC

${ }^{41}$ Environmental Change Research Centre, Department of Geography, University College London, London, WC1E 6BT, UK

${ }^{42}$ Centre for Past Climate Change, Department of Geography and Environmental Science, University of Reading, Reading, RG6 6AB, UK

${ }^{43}$ School of Geography, Planning and Environmental Management, The University of Queensland, St Lucia QLD 4072, Australia

${ }^{44}$ Freie Universität Berlin, Geological Sciences, Palaeontology Section, 12249 Berlin, Germany

${ }^{45}$ Biodiversity and Climate Research Centre, Senckenberganlage 25, 60325 Frankfurt, Germany

${ }^{46}$ Center of Marine Sciences (CCMAR), Algarve University, Campus de Gambelas, 8005-139 Faro, Portugal

${ }^{47}$ Portuguese Sea and Atmosphere Institute (IPMA), Rua Alfredo Magalhães Ramalho 6, 1495-006 Lisbon, Portugal

${ }^{48}$ School of Geography, Environment and Earth Sciences, Victoria University of Wellington, P.O. Box 600, Wellington 6140, New Zealand

${ }^{49}$ Graduate School of Environmental Earth Science, Hokkaido University, N10-W5 Kita-ku, Sapporo 060-0810, Japan

${ }^{50}$ Unitat de Botànica, Facultat de Biociències, Universitat Autònoma de Barcelona, 08193 Bellaterra, Cerdanyola del Vallès, Spain

${ }^{51}$ C.N.R. - Istituto per la Dinamica dei Processi Ambientali, Laboratorio di Palinologia e Paleoecologia, Piazza della Scienza 1, 20126 Milano, Italy

${ }^{52}$ Department of Earth Sciences, Palynology and Palaeobotany Section, National Museums of Kenya, P.O. Box 40658, Nairobi, 00100, Kenya

${ }^{53}$ Department of Plant Sciences, University of the Free State, P.O. Box 339, Bloemfontein, South Africa 
${ }^{54}$ Graduate School of Life and Environmental Sciences, Kyoto Prefectural University, 1-5 Hangi-cho, Shimogamo, Sakyo-ku, Kyoto 606-8522, Japan

${ }^{55}$ Department of Geography, University of Exeter, Amory Building, Rennes Drive, Exeter, EX4 4RJ, UK

${ }^{56}$ Department of Paleoecology and Landscape Ecology, Institute for Biodiversity and Ecosystem Dynamics, Universiteit van Amsterdam, Science Park 904, 1098 XH Amsterdam, the Netherlands

${ }^{57}$ Department of Biological Sciences, Florida Institute of Technology, Melbourne, FL 32901, USA

${ }^{58}$ GNS Science1 Fairway Drive, Avalon P.O. Box 30-368, Lower Hutt 5010, New Zealand

${ }^{59}$ Department of Earth Sciences, Montana State University, Bozeman, MT 59717, USA

${ }^{60}$ U.S. Geological Survey, 926A National Center, Reston, VA 20192, USA

Correspondence to: Maria F. Sanchez Goñi (maria.sanchez-goni@u-bordeaux.fr, maria-fernanda.sanchez-goni@ephe.sorbonne.fr)

Received: 20 January 2017 - Discussion started: 28 February 2017

Revised: 26 July 2017 - Accepted: 7 August 2017 - Published: 11 September 2017

\begin{abstract}
Quaternary records provide an opportunity to examine the nature of the vegetation and fire responses to rapid past climate changes comparable in velocity and magnitude to those expected in the 21 st-century. The best documented examples of rapid climate change in the past are the warming events associated with the Dansgaard-Oeschger (D-O) cycles during the last glacial period, which were sufficiently large to have had a potential feedback through changes in albedo and greenhouse gas emissions on climate. Previous reconstructions of vegetation and fire changes during the $\mathrm{D}-\mathrm{O}$ cycles used independently constructed age models, making it difficult to compare the changes between different sites and regions. Here, we present the ACER (Abrupt Climate Changes and Environmental Responses) global database, which includes 93 pollen records from the last glacial period (73-15 ka) with a temporal resolution better than 1000 years, 32 of which also provide charcoal records. A harmonized and consistent chronology based on radiometric dating $\left({ }^{14} \mathrm{C},{ }^{234} \mathrm{U} /{ }^{230} \mathrm{Th}\right.$, optically stimulated luminescence (OSL), ${ }^{40} \mathrm{Ar} /{ }^{39} \mathrm{Ar}$-dated tephra layers) has been constructed for 86 of these records, although in some cases additional information was derived using common control points based on event stratigraphy. The ACER database compiles metadata including geospatial and dating information, pollen and charcoal counts, and pollen percentages of the characteristic biomes and is archived in Microsoft Access ${ }^{\mathrm{TM}}$ at https://doi.org/10.1594/PANGAEA.870867.
\end{abstract}

1

\section{Introduction}

There is considerable concern that the velocity of projected 21 st-century climate change is too fast to allow terrestrial organisms to migrate to climatically suitable locations for their survival (Loarie et al., 2009; Burrows et al., 2011, 2014; Ordonez et al., 2013). The expected magnitude and velocity of 21 st-century climate warming is comparable to abrupt climate changes depicted in the geologic records, specifically the extremely rapid warming that occurred multiple times during the last glacial period (Marine Isotope Stages (MISs) 4 through 2; 73.5-14.7 ka). The estimated increases in Greenland atmospheric temperature were $5-16{ }^{\circ} \mathrm{C}$ (Capron et al., 2010) and the duration of the warming events between 10 and 200 years (Steffensen et al., 2008). These events are a component of longer-term millennial-scale climatic variability, a pervasive feature throughout the Pleistocene (Weirauch et al., 2008); the events were originally identified from Greenland ice archives (Dansgaard et al., 1984) and in North Atlantic Ocean records (Bond and Lotti,
1995; Heinrich, 1988) and termed Dansgaard-Oeschger (D$\mathrm{O})$ cycles and Heinrich events (HE).

$\mathrm{D}-\mathrm{O}$ events are registered worldwide, although the response to D-O warming events is diverse and regionally specific (see, e.g., Fletcher et al., 2010; Harrison and Sanchez Goñi, 2010; Sanchez Goñi et al., 2008) and not a linear response to either the magnitude or the duration of the climate change in Greenland. Given that the magnitude, length and regional expression of the component phases of each of the D-O cycles varies (Johnsen et al., 1992; Sanchez Goñi et al., 2008), they provide a suite of case studies that can be used to investigate the impact of abrupt climate change on terrestrial ecosystems.

The ACER (Abrupt Climate change and Environmental Responses) project was launched in 2008 with the aim of creating a global database of pollen and charcoal records from the last glacial period (73-15 ka) which would allow us to reconstruct the regional vegetation and fire changes in response to glacial millennial-scale variability and evaluate the simulated regional climates resulting from freshwater changes under glacial conditions. Although there are 232 pollen records 
covering the last glacial period worldwide, only 93 have sufficient resolution and dating control to show millennial-scale variability (Harrison and Sanchez Goñi, 2010). It was necessary to reevaluate and harmonize the chronologies of these individual records to be able to compare patterns of change from different regions. In this paper, we present the ACER pollen and charcoal database, including the methodology used for chronological harmonization and explore the potential of this data set by comparing two harmonized pollen sequences with other palaeoclimatic records. Such a comparison illustrates the novel opportunities for the spatial analyses of the impacts of global climate events using this research tool.

\section{Data and methods}

\subsection{Compilation of the records}

The ACER pollen and charcoal database includes records covering part of or all of the last glacial period with a sampling resolution from a few centuries to less than 1000 years, which allows the identification of centennial-scale vegetation changes similar in duration to the current global climate change. These records were collected as raw data, through direct contact with researchers or from the freely available European and African Pollen Databases. Four records were digitized from publications using the Grapher ${ }^{\mathrm{TM}} 12$ (Golden Software, LLC) because the original data were either lost (Kalaloch: Heusser, 1972 and Tagua Tagua: Heusser, 1990) or are not publicly available (Lac du Bouchet: Reille et al., 1998 and Les Echets: de Beaulieu and Reille, 1984). These digitized records are available as pollen percentages rather than raw counts. All the records are listed and described in https://doi.org/10.1594/PANGAEA.870867.

\subsection{Harmonization of database chronologies}

The chronology of each of the records was originally built as a separate entity. In order to produce harmonized chronologies for the ACER database, decisions had to be made about the types of dates to use, the reference age for the "present" (b2k or the year 1950), the choice of calibration curve, the treatment of radiocarbon age reservoirs, and the software used for age-model construction.

Radiometric ages $\left({ }^{14} \mathrm{C},{ }^{235} \mathrm{U} /{ }^{230} \mathrm{Th}\right.$, optically stimulated luminescence (OSL), ${ }^{40} \mathrm{Ar} /{ }^{39} \mathrm{Ar}$ ) and radiometrically dated tephras are given preference in the construction of the age models. The tephra ages were obtained either through direct ${ }^{40} \mathrm{Ar} /{ }^{39} \mathrm{Ar}$ dating of the tephra or ${ }^{14} \mathrm{C}$ dating of adjacent organic material (Table 1). When a radiometric or tephra date was obtained on a unit of sediment, the depth of the midpoint of this unit was used for the date in the age modeling. Both the age estimate and the associated errors (SD) are required for age-model construction. When the positive and negative standard deviations were different, the larger value was used for age-model construction. In cases where the error measurements on the radiometric dates were unknown (e.g., site F2-92-P29), no attempt was made to construct a harmonized age model.

Measured ${ }^{14} \mathrm{C}$ ages were transformed to calendar ages, to account for the variations in the atmospheric ${ }^{14} \mathrm{C} /{ }^{12} \mathrm{C}$ ratio through time. Radiocarbon ages from marine sequences were corrected before calibration to account for the reservoir effect whereby dates have old ages because of the delay in exchange rates between atmospheric $\mathrm{CO}_{2}$ and ocean bicarbonate and the mixing of young surface waters with upwelled old deep waters. We used the IntCal13 and Marine13 calibration curves for terrestrial and marine ${ }^{14} \mathrm{C}$ dates, respectively (Reimer et al., 2013), which are the calibration curves approved by the radiocarbon community (Hajdas, 2014). Although studies have shown that the radiocarbon ages of tree rings from the Southern Hemisphere ( $\mathrm{SH})$ are ca. 40 years older than Northern Hemisphere $(\mathrm{NH})$ trees formed at the same time (Hogg et al., 2013), this difference is smaller than the laboratory errors on most of the ${ }^{14} \mathrm{C}$ dates, and, since the Marine13 calibration curve does not distinguish between SH and $\mathrm{NH}$ sites, we use the $\mathrm{NH}$ IntCal13 calibration curve for all the records.

The Marine13 calibration curve includes a default 400year reservoir correction. We adjusted this correction factor for all the 26 marine records included in the database using the regional marine reservoir age $(\Delta R)$ in the Marine Reservoir Correction Database (http://calib.org/calib/). For 20 marine records, the correction factor was based on a maximum of the 20 closest sites within $1000 \mathrm{~km}$ to a specific site; for the remaining six marine records this factor was based on a maximum of the 20 closest sites within $3000 \mathrm{~km}$. When $\Delta R \mathrm{~s}$ were homogeneous, a value \pm 100 years, over this area we used the mean of the 10 sites within $100 \mathrm{~km}$ to provide a reservoir correction for the site. When there was heterogeneity in $\Delta R$ values within the $3000 \mathrm{~km}$ target area, we selected only the sites with homogeneous $\Delta R$ within 100 $200 \mathrm{~km}$. Temporal variations in $\Delta R$ were not taken into account since they are currently not well established for many locations.

For periods beyond the limit of ${ }^{14} \mathrm{C}$ dating $(\sim 45 \mathrm{ka})$ and for the few records without radiometric dating, additional chronological control points were obtained based on "event stratigraphy", specifically the identification of D-O warming events and MIS boundaries (Table 1). No assumption was made that core tops were modern for both marine and terrestrial cores. The ages of D-O warming events and those of the MIS boundaries were based on the stratigraphy of core MD95-2042, from the southern Iberian margin (Table 1). The similarity of the planktonic foraminifera $\delta^{18} \mathrm{O}$ record from MD95-2042 to the $\delta^{18} \mathrm{O}$ record from Greenland allowed us to match ages of individual $\mathrm{D}-\mathrm{O}$ cycles, while the benthic foraminifera $\delta^{18} \mathrm{O}$ record from MD95-2042 allowed us to match ages of MIS boundaries (Shackleton et al., 2000). Both $\mathrm{D}-\mathrm{O}$ and MIS ages were directly transferred to the MD95- 
Table 1. Harmonized control points used for age models when radiometric ages $\left({ }^{14} \mathrm{C}, \mathrm{OSL},{ }^{40} \mathrm{Ar} /{ }^{39} \mathrm{Ar},{ }^{234} \mathrm{U} /{ }^{230} \mathrm{Th}\right)$ were not available.

\begin{tabular}{|c|c|c|c|c|c|c|}
\hline \multicolumn{2}{|c|}{ Event stratigraphy ${ }^{4-9}$} & \multirow{5}{*}{$\begin{array}{l}\text { GICC05 }^{11} \\
\text { b1950 } \\
\text { age ka }\end{array}$} & \multirow{3}{*}{$\begin{array}{l}\text { Tephra layers }{ }^{11-22} \\
\text { K-Ah }^{12} \\
\text { Mazama Ash }^{13}\end{array}$} & \multirow{3}{*}{$\begin{array}{l}\begin{array}{l}\text { ACER } \\
\text { chronology } \\
\text { age }{ }^{14} \mathrm{C}^{2}\end{array} \\
6.28 \\
6.84\end{array}$} & \multirow{3}{*}{$\begin{array}{l}\text { ACER } \\
\text { age ka }\end{array}$} & \multirow{3}{*}{$\begin{array}{l}\text { Uncertainties }{ }^{11,27} \\
\text { years } \\
130 \\
50\end{array}$} \\
\hline & & & & & & \\
\hline & & & & & & \\
\hline & & & Rotoma $^{14}$ & 8.53 & & 10 \\
\hline & & & U-Oki ${ }^{15}$ & & $10^{3}$ & 300 \\
\hline \multirow{3}{*}{\multicolumn{2}{|c|}{$\begin{array}{l}\text { Onset } \\
\text { Holocene }\end{array}$}} & 11.65 & & & 11.65 & 50 \\
\hline & & & & & & \\
\hline & & & Rotorua $^{14}$ & 13.08 & & 50 \\
\hline \multirow[t]{8}{*}{ MIS $1 / 2$} & $\mathrm{D}-\mathrm{O} 1$ & 14.6 & & & 14.6 & 93 \\
\hline & & & Rerewhakaaitu $^{16}$ & 14.7 & & 95 \\
\hline & & & $\mathrm{NYT}^{17}$ & & $14.9^{3}$ & 400 \\
\hline & & & Sakate $^{18}$ & 16.74 & & 160 \\
\hline & & & $\mathrm{Y}-2^{19}$ & 18.88 & & 230 \\
\hline & & & & & 21 & \\
\hline & & & Kawakawa/Oruanui ${ }^{20}$ & 21.30 & & 120 \\
\hline & $\mathrm{D}-\mathrm{O} 2$ & 23.29 & & & 23.29 & 298 \\
\hline \multirow[t]{21}{*}{ MIS $2 / 3$} & D-O 3 & 27.73 & & & 27.73 & 416 \\
\hline & & & $\mathrm{AT}^{12}$ & 24.83 & & 90 \\
\hline & $\mathrm{D}-\mathrm{O} 4$ & 28.85 & & & 28.85 & 449 \\
\hline & & & TM-15 & & $31^{3,25}$ & 8000 \\
\hline & D-O 5 & 32.45 & & & 32.45 & 566 \\
\hline & D-O 6 & 33.69 & & & 33.69 & 606 \\
\hline & D-O 7 & 35.43 & & & 35.43 & 661 \\
\hline & & & TM-18 & & $37^{3,25}$ & 3000 \\
\hline & D-O 8 & 38.17 & & & 38.17 & 725 \\
\hline & & & Y-5 ${ }^{19}$ & & $39.28^{3}$ & 110 \\
\hline & & & Akasuko $^{21}$ & 40.73 & & 1096 \\
\hline & D-O 9 & 40.11 & & & 40.11 & 790 \\
\hline & D-O 10 & 41.41 & & & 41.41 & 817 \\
\hline & D-O 11 & 43.29 & & & 43.29 & 868 \\
\hline & & & Breccia zone ${ }^{21}$ & 43.29 & & 955 \\
\hline & D-O 12 & 46.81 & & & 46.81 & 956 \\
\hline & D-O 13 & 49.23 & & & 49.23 & 1015 \\
\hline & D-O 14 & 54.17 & & & 54.17 & 1150 \\
\hline & & & TM-19 & & $55^{3,25}$ & 2000 \\
\hline & D-O 15 & 55.75 & & & 55.75 & 1196 \\
\hline & D-O 16 & 58.23 & & & 58.23 & 1256 \\
\hline \multirow[t]{3}{*}{ MIS 3/4 } & D-O 17 & 59.39 & & & 59.39 & 1287 \\
\hline & onset HS 6 & $64.6^{9}$ & & & 64.6 & 1479 \\
\hline & D-O 18 & $65^{9}$ & & & 65 & 1518 \\
\hline
\end{tabular}


Table 1. Continued.

\begin{tabular}{|c|c|c|c|c|c|c|}
\hline \multicolumn{2}{|c|}{ Event stratigraphy ${ }^{4-9}$} & \multirow{2}{*}{$\begin{array}{l}\text { GICC05 } \\
\text { b1950 } \\
\text { age ka } \\
72.28\end{array}$} & \multirow[t]{2}{*}{ Tephra layers ${ }^{11-22}$} & \multirow{2}{*}{$\begin{array}{l}\text { ACER } \\
\text { chronology } \\
\text { age }{ }^{14} \mathrm{C}^{2}\end{array}$} & \multirow{2}{*}{$\begin{array}{l}\text { ACER } \\
\text { age ka }\end{array}$} & \multirow{2}{*}{$\begin{array}{l}\text { Uncertainties }^{11,27} \\
\text { years }\end{array}$} \\
\hline MIS 4/5 & $\begin{array}{l}\text { D-O } 19 \\
\text { (onset Ognon II) }\end{array}$ & & & & & \\
\hline & $\begin{array}{l}\text { D-O } 20 \\
\text { (onset Ognon I) }\end{array}$ & 76.4 & & & 76.4 & 1449 \\
\hline & $\begin{array}{l}\text { C } 20 \\
\text { (stadial I) }\end{array}$ & $77^{9}$ & & & 77 & 1476 \\
\hline & MS insolation $15^{\circ} \mathrm{S}^{1}$ & 81 & & & 81 & 1504 \\
\hline \multirow[t]{5}{*}{ MIS 5.1} & $\begin{array}{l}\text { D-O } 21 \\
\text { (onset St Germain II) }\end{array}$ & $82.9^{8}$ & & & 82.9 & 1458 \\
\hline & C 21 & $85^{10}$ & & & 85 & 1448 \\
\hline & & & $\mathrm{Vico}^{22}$ & & $87^{3}$ & 7000 \\
\hline & & & Aso- $4^{23}$ & & $89^{3}$ & 7000 \\
\hline & & & Ash- $10^{24}$ & & $100^{3}$ & 1540 \\
\hline \multicolumn{3}{|l|}{ MIS 5/6 } & & & $135^{26}$ & 2500 \\
\hline \multicolumn{7}{|c|}{ 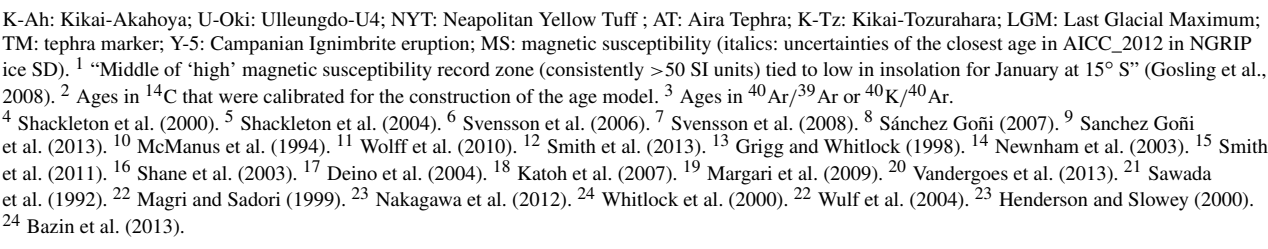 } \\
\hline
\end{tabular}

2042 pollen record. The chronology of this pollen record was in turn transferred to the other European pollen records assuming, within the uncertainties of the age models and the temporal resolution of the records, synchronous afforestation during D-O warming. Note that only a limited number of D-O events were used to constrain the age models of the European records (Supplement Table S1); i.e., not all the afforestation episodes were attributed to a D-O warming event. The uncertainties for the event-based ages up to D-O 17 are from data summarized in Wolff et al. (2010) and from AICC_2012 in NGRIP ice SD (Bazin et al., 2013) for older events. These uncertainties limit the discussion of the timing of European tree colonization during a D-O warming.

Non-radiocarbon dates are presented in the same BP notation as radiocarbon determinations. The modern reference date is taken as $1950 \mathrm{AD}(\mathrm{BP})$, since this is the reference date for the GICC05 chronology (Wolff et al., 2010).

Bayesian age modeling (e.g., using OxCAL, Bchron or $\mathrm{BACON}$ ) requires information about accumulation rates and other informative user-defined priors (Blaauw and Christen, 2011) that are difficult to obtain for the relatively long ACER records. Moreover, BACON and Bchron (Haslett and Parnell, 2008; Parnell et al., 2008) do not handle sudden shifts in accumulation rate very well, and such shifts are not uncommon across deglaciation and stadial time periods. We therefore use the classical age-modeling approach in the CLAM software
(Blaauw, 2010), implemented in R ( $\mathrm{R}$ version 3.3.1) (R Development Core Team, 2016), to construct the age model.

Several age models were built for each record using the calibrated distribution of the radiometric dates: (a) linear interpolation between dated levels; (b) linear or higher-order polynomial regression; and (c) cubic, smoothed or locally weighted splines (Supplement Table S1). For general guidance, we have selected the age model that has goodness-of-fit values that are among the lowest but that are not necessarily the lowest (Supplement Table S2). The linear interpolation model was favored because it is generally the most parsimonious solution for records with no age reversals. For regression and spline models, the selection of the model was based on a combination of visual inspection and goodness-of-fit values; this allows the selection of the model including most of the outliers and realistic changes in sedimentation rates. If none of the regression or spline models provided a better fit, we built age models after excluding outliers proposed by the original authors (Supplement Table S1). The database includes information on the single "best" age model and the $95 \%$ confidence interval estimated from the 10000 iterated age-depth models (weighted mean) for every sample depth.

\subsection{The structure of the database}

The ACER pollen and charcoal data set is archived in a Microsoft Access $^{\mathrm{TM}}$ relational database. There are six main tables (Fig. 1). 


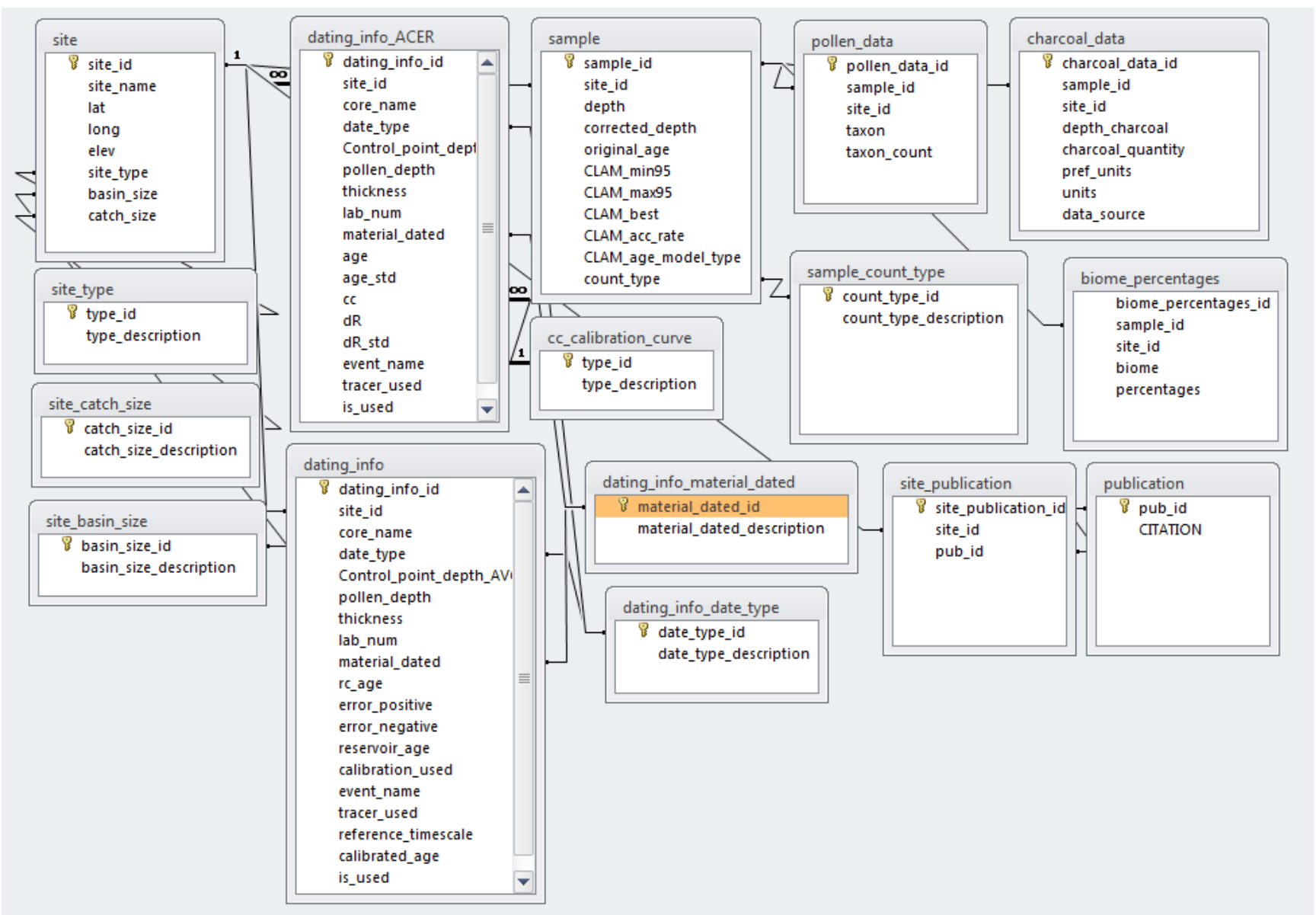

Figure 1. ACER database structure in ACCESS format.

1. Site Metadata. This table includes the original site name, geographical coordinates (latitude and longitude in decimal degrees, elevation in meters above or below sea level) and additional metadata including site type (marine or terrestrial), basin size and catchment size. Basin size and catchment size determine the size of the area sampled by the record (or pollen source area: see Prentice, 1988) but are not always recorded in the original publication or known very accurately. A categorical classification (small, medium, large, very large) is recorded in the database where these categories are specified by ranges in square kilometers. The details of the original publication of the data are also given in this table.

2. Sample data. The table records the identification number of each sample (sample ID) at each site (site ID) and provides the depth of the sample (in centimeters from the surface). At only one site, core MD04-2845, a corrected depth is provided on which the new age model is based. The pollen count type (raw pollen count, pollen percentages given by the authors or digitized percentage) is also given. The original age of the sample ac- cording to the published age model when available and the age determined from the best CLAM model (the minimum and the maximum at $95 \%$, the accumulation rate, and the type of model used to obtain this age) are given.

3. Pollen data. The pollen data are recorded as raw counts or as the pollen percentage of each pollen and spore morphotype identified. The table records the identification number of each sample (sample ID), the taxon name and count/percentage. The taxa names were standardized across cores with respect to the accepted use of terms such as type presented in different pollen determination key publications (e.g., Moore et al., 1991; Faegri et al., 1989), and abbreviations and obvious spelling mistakes were removed. The names are listed in a supplementary Excel file at https://doi.org/10.1594/PANGAEA.880501.

4. Charcoal data. The table records the identification number of each sample (sample ID). The charcoal data are recorded by depth (in centimeters from the surface), and information is given on the quantity and unit of mea- 
surement and on the data source. Charcoal abundance is quantified using a number of different metrics; for the majority of abundances, these are given in concentrations, and for a few of them, they are given in percentages.

5. Original dating information. This table contains information on dating for each core at each site. The core name from the original publication is given, and the table provides information on date type (conventional ${ }^{14} \mathrm{C}$, AMS (accelerator mass spectrometer) ${ }^{14} \mathrm{C},{ }^{234} \mathrm{U} /{ }^{230} \mathrm{Th}, \mathrm{OSL},{ }^{40} \mathrm{Ar} /{ }^{39} \mathrm{Ar}$, annual laminations, event stratigraphy, TL (thermoluminiscence)), the average depth assigned to the data in the age-model construction, the dating sample thickness, laboratory identification number, material dated (bulk, charcoal, foraminifera, pollen, tephra, wood), measured radiometric age and associated errors. The marine reservoir age (and associated error) and the radiocarbon calibration curve used in the construction of the original age model, and the original calibrated age, are also given. Dates that are based on recognized events are also listed and identified by the name of the event (event name) and the type of record in which it is detected (tracer used). The column "is_used" corresponds to the dates used by the authors for building the original age models.

6. ACER dating information. The ACER dating information table duplicates the original dating information file, except that it provides information about the explicit corrections and the harmonized control points used to produce the ACER age models (Table 1). Specifically, it gives the calibration curve used (no calibration, IntCal13, Marine13) and the local reservoir age (and uncertainty) for marine cores.

The ACER database allows archiving multiple cores retrieved at the same site (site name followed by the name of the core). In such a case, an age-depth model is constructed for each core and archived in the database.

Additional tables document the codes used in the main tables for, e.g., basin type, basin size, date type, material dated, calibration curve and biome percentage table, which includes selected biomes provided by the authors (Table 2). The taxa defining the pollen percentages of the main forest biomes are those originally published by the authors in the Quaternary Science Reviews special issue (Fletcher et al., 2010; Hessler et al., 2010; Jimenez-Moreno et al., 2010; Takahara et al., 2010). The taxa defining the pollen percentages of the main biomes from Africa (sites Mfabeni and Rumuiku) Australia (sites Caledonia Fen and Wangoom) and New Zealand (site Kohuora) not included in this issue are described in the Supplement.

Each table of the ACCESS database is also available as .csv file: (a) site, (b) sample (original depth-age model and
ACER depth-age model), (c) dating info (original dating information), (d) dating info ACER (harmonized dating information from this work), (e) pollen data (raw data or digitized pollen percentages; pollen percentages of different biomes) (Table 2), (f) unique taxa in database (list of all the identified taxa) and (g) charcoal data (raw or digitized).

\section{Results}

\subsection{The ACER pollen and charcoal database}

ACER database comprises all available pollen and charcoal records covering all or part of the last glacial period (73 to $15 \mathrm{ka}$ ) as of July 2015. It contains 93 well-resolved pollen records ( $<1000$ years between samples), 32 of which include charcoal data, from all the major potential present-day biomes (Fig. 2). There are 2486 unique pollen and spore taxa in the database.

Harmonized age models were constructed for 86 out of the 93 records (Supplement Table S2). The seven sites without harmonized age models are F2-92-P29 (no radiocarbon age errors available), Bear Lake (pollen was counted on one core but sample depths could not be correlated with the cores used for dating), EW-9504 and ODP 1234 (original age models based on correlation with another core, but tie point information was not available), Okarito Pakihi (no dating information available) and Wonderkrater borehole 3 (multiple age reversals). Lake Consuelo, Rice Lake and Wonderkrater have multiple cores (Consuelo: CON1 and CON2; Rice Lake: Rice Lake 79 and Rice Lake 81) but composite depth records were lacking. Given the focus of this study, age models were created only for Lake Consuelo CON1 and Wonderkrater borehole 4 (CON2 and borehole 3 only cover the Holocene). Age models are available for the two cores from Rice Lake, with a hiatus between the two records of about 2000 years (oldest sample at $16000 \mathrm{cal}$ yr BP in core 79 and youngest one at $18000 \mathrm{cal} \mathrm{yrBP}$ in core 81 ). These two cores have to be merged prior to future data analysis. The well-known site of La Grande Pile (de Beaulieu and Reille, 1992) is not included in the ACER database because the high-resolution data are not publicly available, and the poor quality of the .pdf support precluded its digitalization. Other sequences, such as Sokli in Finland, were fragmented and could not be used (Supplement Table S1). These sites are shown at the bottom of the Supplement Table S1.

\subsection{Harmonized vs. original age models}

We generated a total of 774 different age models by applying the different models available in CLAM (linear interpolation, linear regression, 3 orders of higher polynomial regression, cubic spline, and two smooth splines at 0.3 and $0.6^{\circ}$ of freedom and locally weighted spline with different smoothing) to each of the 86 sites compiled. The age models of 45 records are based on linear interpolation (Supplement Ta- 
Table 2. Biomes for which the pollen percentages data are included in the ACER database. Bo forest: boreal forest; Te mountain forest: temperate mountain forest; Te forest: temperate forest; WTe forest: warm temperate forest; Tr forest: tropical forest; Subtr forest: subtropical forest; SE Pine forest: southeastern Pine forest; Gr: grasslands and dry shrublands; Sav: savanah. In Europe, Te forest refers to Mediterranean and Atlantic forests.

\begin{tabular}{|c|c|c|c|c|c|}
\hline \multirow[t]{2}{*}{ Europe } & \multirow[t]{2}{*}{ North America } & Tropics & \multirow[t]{2}{*}{ East Asia } & \multirow[t]{2}{*}{ New Zealand } & \multirow[t]{2}{*}{ Australia } \\
\hline & & American African & & & \\
\hline Te forest & $\begin{array}{l}\text { Bo forest } \\
\text { Te forest } \\
\text { WTe forest } \\
\text { SE Pine Forest }\end{array}$ & $\begin{array}{l}\text { Te mountain forest } \\
\text { WTe forest } \\
\text { Tr forest } \\
\mathrm{Gr}\end{array}$ & $\begin{array}{l}\text { Bo forest } \\
\text { Te forest } \\
\text { WTe forest } \\
\text { Subtr forest } \\
\text { Gr }\end{array}$ & $\begin{array}{l}\text { Te forest } \\
\text { WTe forest }\end{array}$ & $\begin{array}{l}\text { WTe forest } \\
\text { Te mountain forest } \\
\text { Sav }\end{array}$ \\
\hline
\end{tabular}

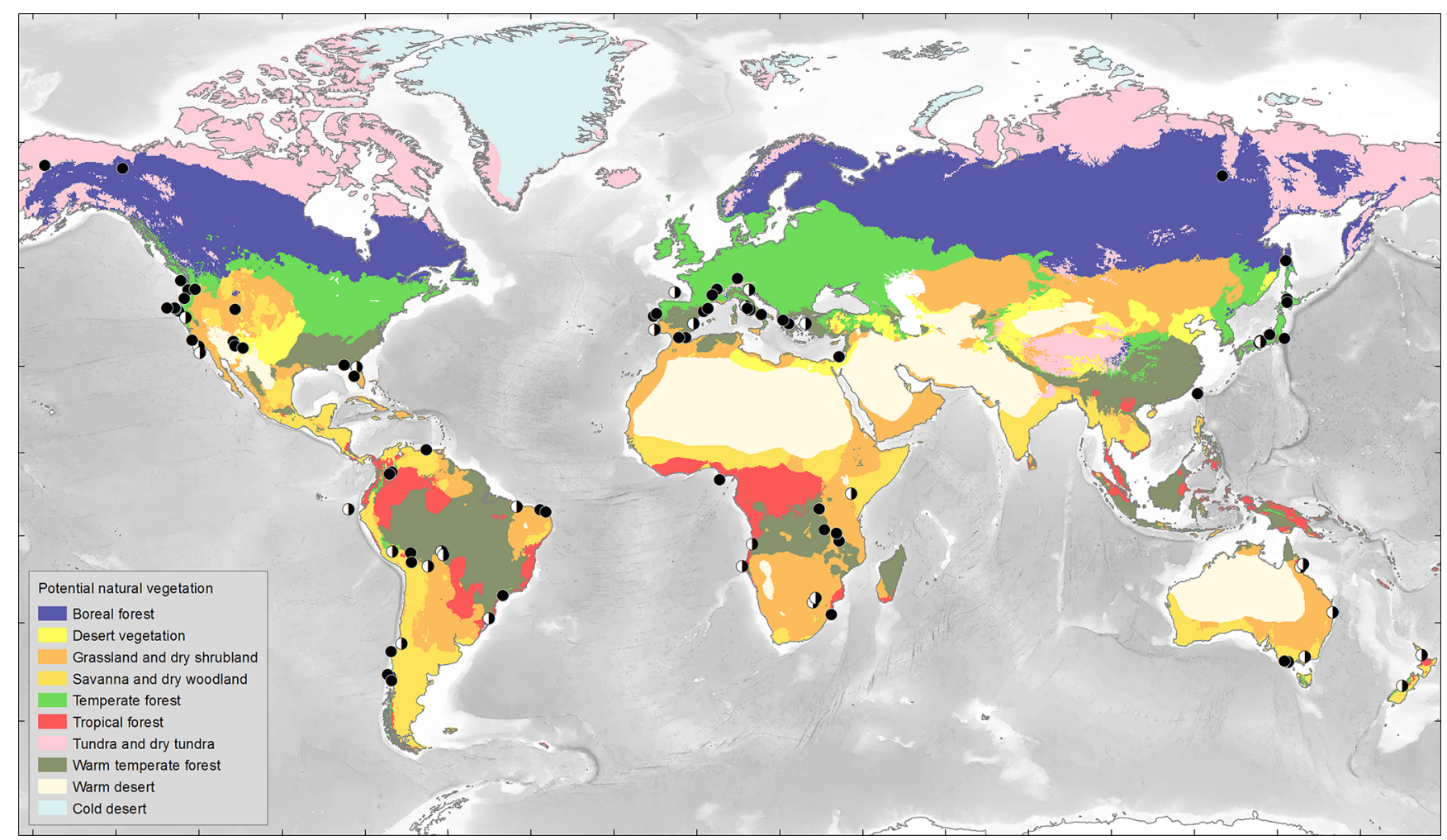

Figure 2. Map with location of the 93 marine and terrestrial pollen sites covering part of or all the last glacial period (MISs 4, 3 and 2). Sites have better resolution than 1 sample per 1000 years. Present-day potential natural vegetation after Levavasseur et al. (2012).

ble S2). The age models of the other records are derived from smooth or locally weighted splines (e.g., Lake Caço, Brazil; Fargher Lake, North America; ODP1078C, southeastern Atlantic margin) or polynomial regression (e.g., Hanging Lake and Carp Lake, North America; Lake Fuquené, Colombia; Valle di Castiglione, Europe) to include as many as possible of the available radiometric dates. Since the focus for age modeling was the last glacial period, age models for the Holocene (11.65 ka-present) and Last Interglacial sensu lato intervals (135-72.28 ka) are not necessarily well constrained.

Selected examples of the original and harmonized age models are illustrated in Figs. 3 and 4. The original age model of marine core MD95-2043, from the western
Mediterranean Sea (Fig. 3a, red curve), was based on tuning the midpoints of the cold to warm D-O transitions with the equivalent midpoints in the alkenone-based sea-surface temperature (SST) record (Cacho et al., 1999). The harmonized age model (black) is based on $21{ }^{14} \mathrm{C}$ ages and two isotopic stratigraphic events (D-O 12 and D-O 14). The two age models are similar, with a mismatch of less than 1000 years for periods older than $35 \mathrm{ka}$ and narrow uncertainties (Fig. 3a). In contrast, the original age model of the terrestrial sequence of Valle di Castiglione, central Italy, published in Fletcher et al. (2010), differs substantially, by several millennia, from the harmonized model in the interval between 50 and $30 \mathrm{ka}$ and has large uncertainties (Fig. 3b). This age 
model was based on two calibrated ${ }^{14} \mathrm{C}$ dates: one ${ }^{40} \mathrm{Ar} /{ }^{39} \mathrm{Ar}$ tephra age (Neapolitan Yellow Tuff; Table 2) and the identification of D-O 8, 12 and 14 while the new age model takes into account the entire number of ${ }^{14} \mathrm{C}$ dates (eight), one ${ }^{40} \mathrm{Ar} /{ }^{39} \mathrm{Ar}$ tephra age and one GICC05-event stratigraphic age (identification of $\mathrm{D}-\mathrm{O} 21$ ). It derives from a third-order polynomial regression model to take into account as many as possible of the radiometric ages available (Supplement Table S2).

The original age model for marine core ODP $1233 \mathrm{C}$ from the southern Pacific Ocean off southern Chile was based on 19 AMS ${ }^{14} \mathrm{C}$ dates calibrated using Calpal 2004 (Heusser et al., 2006) and is very similar to the harmonized age model (Fig. 4a). The use of the new IntCal13 calibration curve is sufficient to explain the small differences between the original and harmonized age models. In contrast, there are major differences between the original and harmonized age models for the terrestrial pollen record of Toushe, Taiwan (Fig. 4b). The original age model (Liew et al., 2006) was based on 24 uncalibrated radiometric dates for the 0-24 ka interval and two dated isotopic events (MIS 3/4 and MIS 4/5), which were dated following Martinson et al. (1987) to 58.96 and $73.91 \mathrm{ka}$, respectively. The harmonized age model is based on calibrated ages from $3 \mathrm{AMS}{ }^{14} \mathrm{C}$ and 28 conventional ${ }^{14} \mathrm{C}$ dates and dating of the MIS 3/4 and MIS 4/5 boundaries. In the ACER chronology, these two events are dated to 59.39 and $72.28 \mathrm{ka}$, respectively. In combination, these differences produce substantially younger ages (by up to 5000 years) for the interval between 50 and $26 \mathrm{ka}$ than in the original age model.

Figure 5 additionally illustrates pollen and micro-charcoal data plotted against the harmonized age models for a few sites from different biomes. This figure highlights the regional response of the vegetation and fire regime to the $\mathrm{D}-\mathrm{O}$ events.

\subsection{Vegetation and climate response to the contrasting D-O 8 and D-O 19 warming events}

Comparison of the vegetation and climate response to warming events in two different regions provides an example of the importance of developing harmonized chronologies. DO 19 and D-O 8 are iconic D-O events, characterized by strong warming in Greenland followed by long temperate interstadials of 1600 (GI 19) and 2000 (GI 8) years, respectively (Wolff et al., 2010). D-O 8 occurred ca. $38.17 \mathrm{ka}$ and was marked by an initial short-lived warming of ca. $11^{\circ} \mathrm{C}$, whereas D-O 19 (ca. $72.28 \mathrm{ka}$ ) was characterized by a maximum warming of ca. $16^{\circ} \mathrm{C}$. The difference in the magnitude of warming suggests that the Northern Hemisphere monsoons would be stronger during D-O 19 than D-O 8, but this is not consistent with speleothem evidence from Hulu Cave (China) indicating that monsoon expansion was more marked during D-O 8 than during D-O 19 (Wang et al., 2001) (Fig. 6). Sanchez Goñi et al. (2008) argued that the smaller increase in $\mathrm{CH}_{4}$ during D-O 19 , by ca. $100 \mathrm{ppbv}$, than during D-O 8, by ca. 200 ppbv, was because the expansion of the East Asian monsoon (and hence of regional wetlands) was weaker during D-O 19 due to the differences in precession during the two events (Fig. 6). Differences in the strength of the monsoons between GI 8 (precession minima, high seasonality) and GI 19 (precession maxima, low seasonality) can also be tested using evidence from the pollen record of Toushe Basin, which lies under the influence of the East Asian monsoon. This record shows a similar development of moisture-demanding subtropical forest, during the two interstadials (Fig. 6), and thus does not support the argument that the East Asian monsoon was weaker/less expanded during GI 19 than during GI 8. However, Toushe Basin lies in the tropical belt $\left(23^{\circ} \mathrm{N}\right)$ and is likely to be less sensitive to changes in monsoon extent than more marginal sites such as Hulu Cave $\left(32^{\circ} \mathrm{N}\right)$.

Previous works have also hypothesized that the Mediterranean forest and climate were tightly linked to the Asian and African monsoon through the Rodwell and Hoskins zonal mechanism (Marzin and Braconnot, 2009; Sanchez Goñi et al., 2008) or through shifts in the mean latitudinal position of the Intertropical Convergence Zone (Tzedakis et al., 2009). Data from Hulu cave (Wang et al., 2001) and the western Mediterranean region (MD95-2042 and SU81-18 twin pollen sequences) show that during warming events occurring at minima in precession, such as $\mathrm{D}-\mathrm{O} 8$, monsoon intensification is stronger and associated with a marked seasonality in the Mediterranean region (strong summer dryness) and, therefore, a strong expansion of the Mediterranean forest and decrease in the summer dry-intolerant Ericaceae (Fig. 6) (Sánchez Goñi et al., 1999, 2000). Actually, we observe parallel strong and weak increases in the East Asian monsoon and Mediterranean forest during GI 8 and GI 19, respectively. However, here again there is a discrepancy between the harmonized Toushe pollen sequence and that from the Hulu cave and the western Mediterranean region: the Mediterranean forest and monsoon during D-O 8 strongly increased, while the subtropical forest cover weakly expanded. The different latitudinal position of the Toushe Basin $\left(23^{\circ} \mathrm{N}\right)$ in the tropical region and that of the Hulu Cave $\left(32^{\circ} \mathrm{N}\right)$ and the southern Iberian margin sequence $\left(37^{\circ} \mathrm{N}\right)$, both in the subtropical region, could explain such a discrepancy. A comprehensive analysis of differences in the magnitude of monsoon expansion between D-O 8 and D-O 19 is now possible because of the creation of robust and standardized age models for the ACER records.

Besides the study of the monsoon variability, the ACER database also has the potential to reconstruct land cover changes through time to evaluate changes in vegetationalbedo feedback, to recover the expansion and contraction of different taxa during the $\mathrm{D}-\mathrm{O}$ cycles (i.e., using isolines), to perform spatial climatic reconstructions, and to evaluate climate and vegetation models dealing with the rapid climatic variability. The construction of vegetation and climate maps 

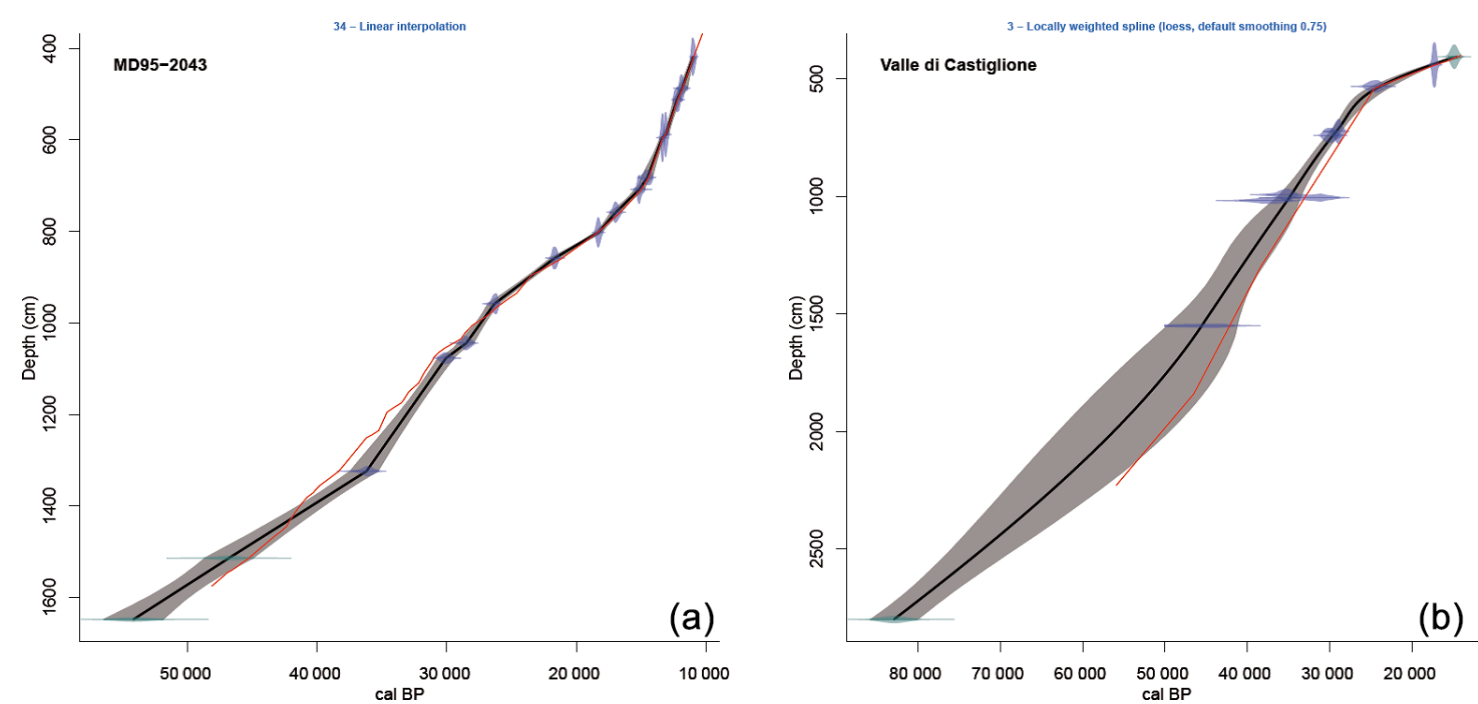

Figure 3. (a) Linear age model of the marine core MD95-2043 and (b) third-order polynomial age model of the terrestrial sequence Valle di Castiglione (Italy). Red line: original age model with the control points. Black line: harmonized age model based on radiometric dating and event stratigraphy. Blue: calibrated ${ }^{14} \mathrm{C}$ distribution. Green: non- ${ }^{14} \mathrm{C}$ age distribution (Ar/Ar, OSL, event stratigraphy). Grey shading: age uncertainties.
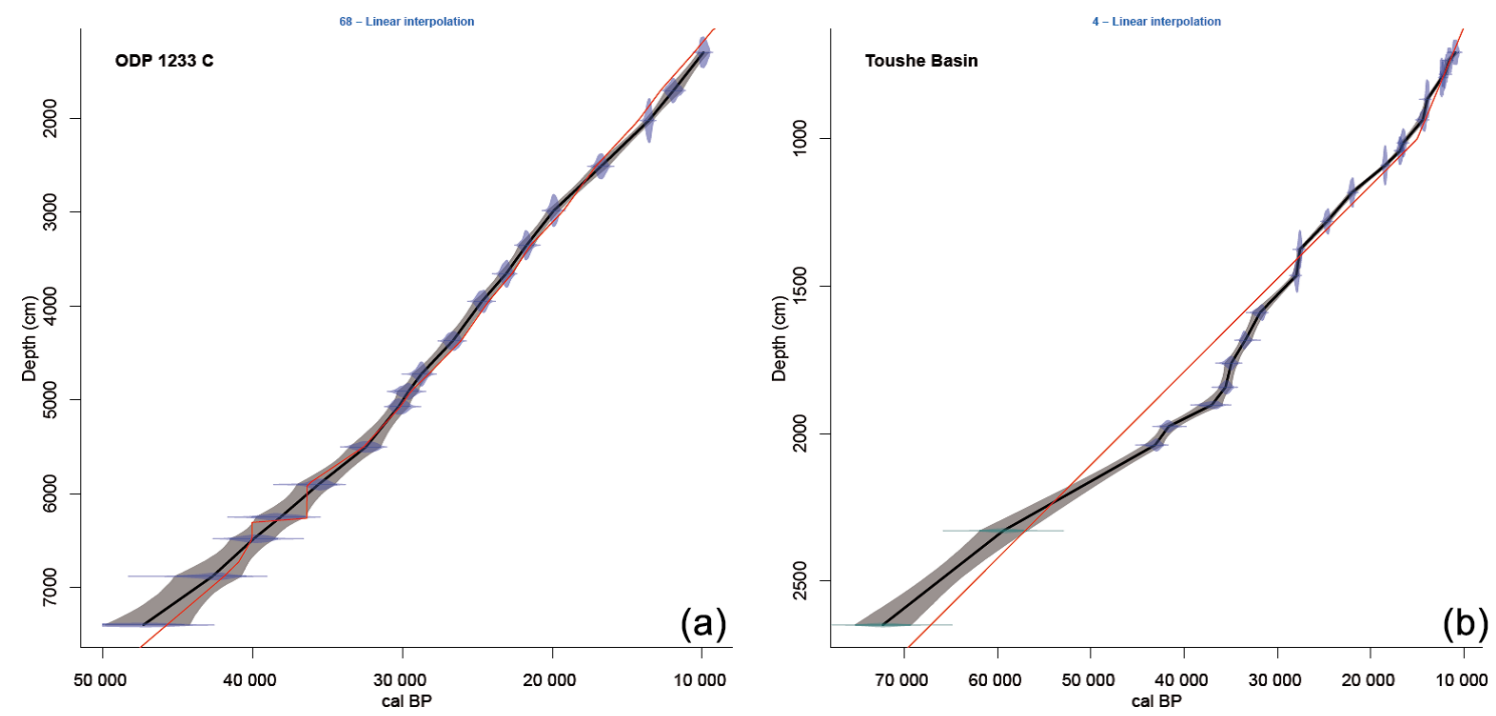

Figure 4. (a) Linear age model of the marine core ODP $1233 \mathrm{C}$ and (b) linear age model of the terrestrial sequence Toushe (Taiwan). Red line: original age model with the control points. Black line: harmonized age model based on radiometric dating and event stratigraphy. Blue: calibrated ${ }^{14} \mathrm{C}$ distribution. Green: non- ${ }^{14} \mathrm{C}$ age distribution (Ar/Ar, OSL, event stratigraphy). Grey shading: age uncertainties.

for different time slices and evaluating model simulations can be continuously improved by implementing the ACER database version 1 (July 2015) with new chronologically harmonized sites.

\section{Data availability}

Data used for this study are available at https://doi.org/10.1594/PANGAEA.870867 (Sánchez Goñi et al., 2017).

\section{Conclusions}

The ACER pollen and charcoal database (ACER 1.0) comprises all available pollen and charcoal records covering part or all of the last glacial period, as of July 2015. We foresee future updates of the ACER database by the research community with newly published pollen and charcoal records. For consistency, age models for new sites should be constructed using the strategy described here. 

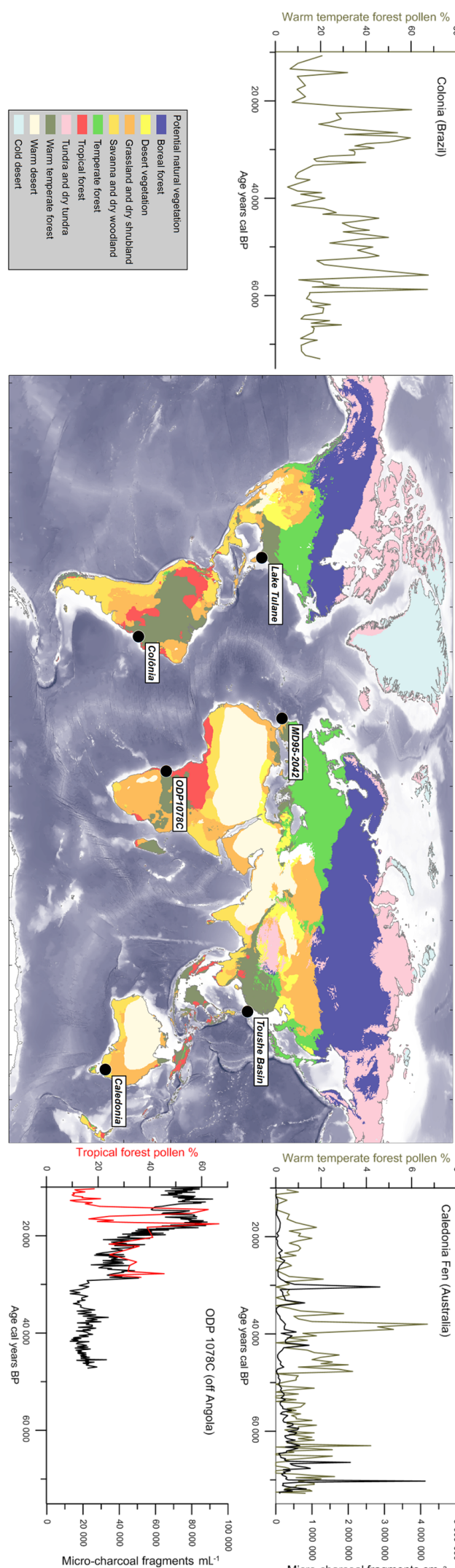
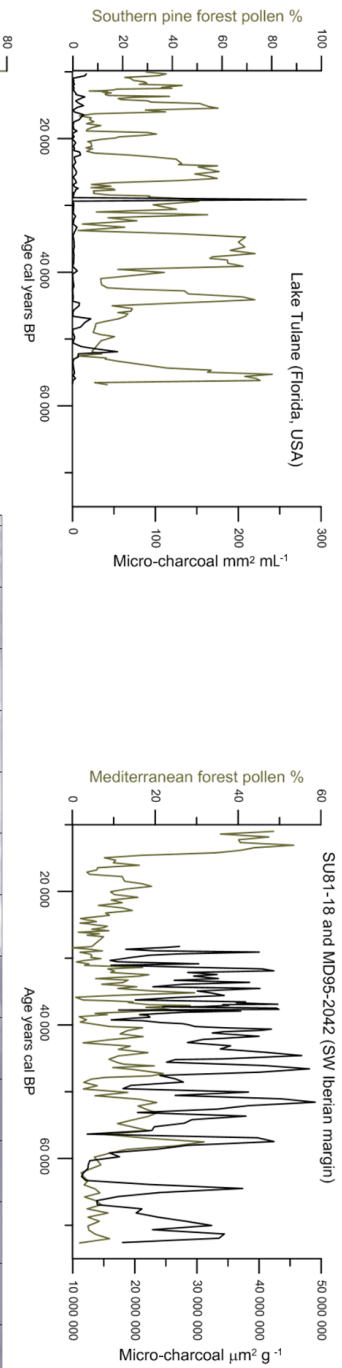

Figure 5. Pollen (green: warm temperate forest; red: tropical forest) and charcoal (black) curves from six sites plotted against the harmonized age model. 


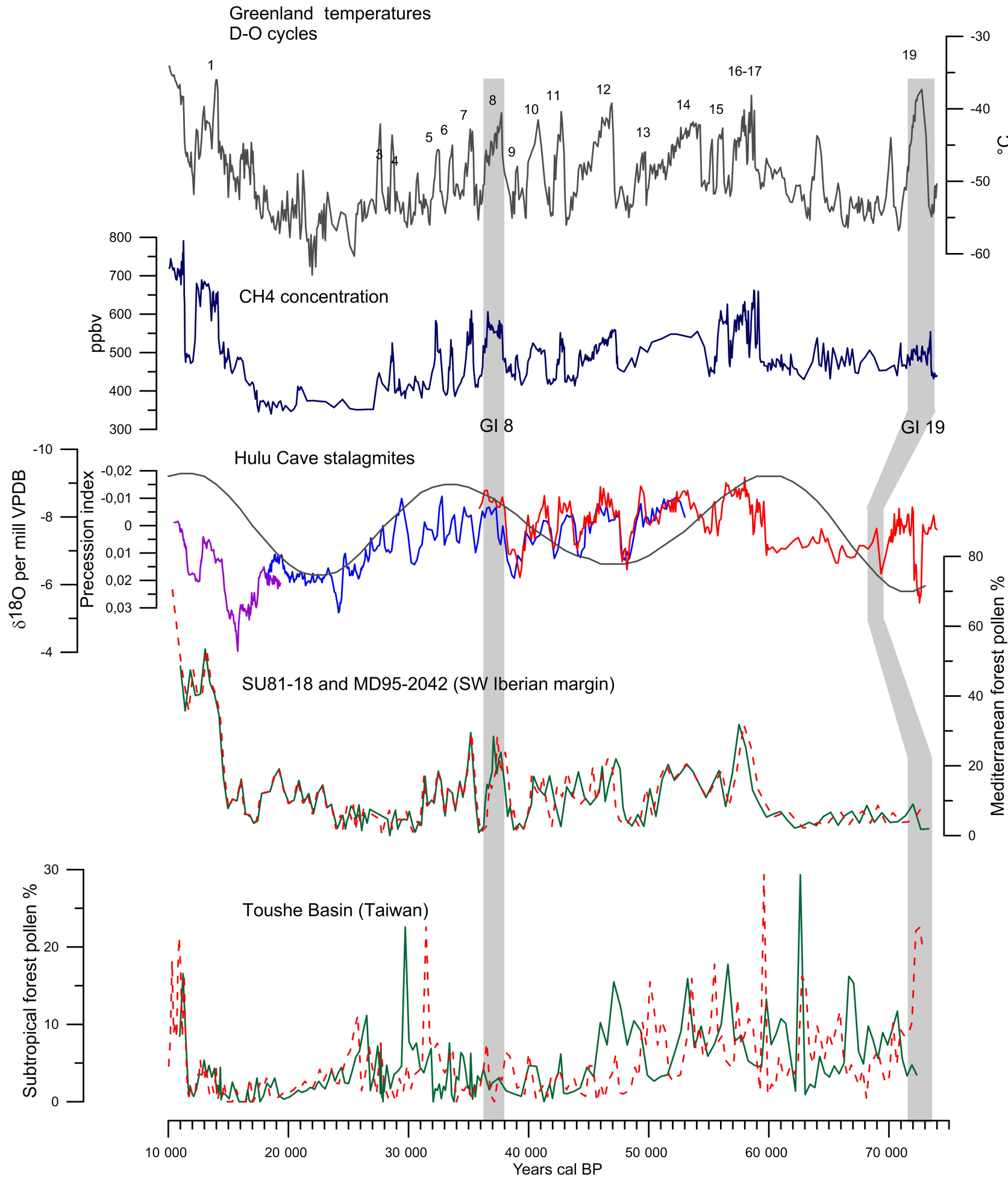

Figure 6. Comparison of pollen sequences from the Toushe Basin (Taiwan) and the SW Iberian margin (cores MD95-2042 (Desprat et al., 2015; Sanchez Goñi et al., 2008) and SU 81-18 (23 500-10 000 cal years BP) (Lézine and Denèfle, 1997)) for the interval 73-23.5 ka. Green line: new harmonized age model; dashed red line: original age model. Grey vertical bands indicate the duration of GI 8, GI 16-17 and GI 19. Also shown are the comparison with the Greenland temperature record (black) (Huber et al., 2006; Landais et al., 2005; Sanchez Goñi et al., 2008), the atmospheric $\mathrm{CH}_{4}$ concentration (blue) record (Chappellaz et al., 1997; Flückiger et al., 2004), compiled Hulu Cave $\delta{ }^{18} \mathrm{O}$ speleothem records (PD in purple, MSD in green and MSL in blue) (Wang et al., 2001) and the precession index (Laskar et al., 2004). Note the mismatch in the timing of GI 19 between the Greenland and pollen harmonized age models and the chronology of Hulu Cave. 
The harmonization of the ACER age models in the ACER 1.0 database increases the consistency between records by (a) calibrating all the radiocarbon dates using the recommended IntCal13 and Marine 13 calibration curves, (b) using the same ages for non-radiometric control points and basing these on the most recent Greenland ice core chronology (GICC05), and (c) using the CLAM software to build the age models and taking account of dating uncertainties. While these harmonized age models may not be better than the original models, they have the great advantage of ensuring comparability between pollen and charcoal records from different regions of the world. As we have shown in the preliminary analyses of monsoon-related vegetation changes during D-O 8 and D-O 19, this will facilitate regional comparisons of the response to rapid climate changes.

The same strategy for age-model harmonization is now being applied to the sea-surface temperature records from the last glacial period that have been compiled by the ACERINTIMATE group (http://www.ephe-paleoclimat.com/acer/ ACER\%20INTIMATE.htm). This will ensure that the terrestrial and marine databases share a common chronological framework, a considerable step towards improving our knowledge of the interactions between oceans and land that underlie the nature and timing of abrupt climatic changes.

\section{The Supplement related to this article is available online at https://doi.org/10.5194/essd-9-679-2017-supplement.}

Author contributions. MFSG, SD and ALD developed the harmonized age models, ALD developed the ACER database in ACCESS, FB participated in the construction of age models, and JMPM extracted the pollen percentage of the dominant biomes from the European sequences compiled in the ACER database. MFSG and SPH wrote the manuscript. The remaining authors are listed alphabetically and are data contributors (see their respective data set in Table S1 in the Supplement). All data contributors (listed in Table S1) were contacted for the authorization of data publishing and offered coauthorship. All the authors have critically reviewed the manuscript. Any use of trade, firm or product names is for descriptive purposes only and does not imply endorsement by the US Government.

Competing interests. The authors declare that they have no conflict of interest.
Acknowledgements. The members of the ACER project wish to thank the QUEST-DESIRE (UK and France) bilateral project, the INQUA International Focus Group ACER and the INTIMATE-COST action for funding a suite of workshops to compile the ACER pollen and charcoal database and the workshop on ACER chronology that allow setting the basis for harmonizing the chronologies. We thank Maarten Blaauw for constructive discussions leading to the construction of age models. Josué M. Polanco-Martinez was funded by a Basque Government postdoctoral fellowship (POS_2015_1_0006) and Sandy P. Harrison by the ERC Advanced Grant GC2.0: unlocking the past for a clearer future. We thank Vincent Hanquiez for drawing Fig. 2.

Edited by: Hannes Grobe

Reviewed by: Thomas Giesecke and one anonymous referee

\section{References}

Bazin, L., Landais, A., Lemieux-Dudon, B., Toyé Mahamadou Kele, H., Veres, D., Parrenin, Martinerie, F., P., Ritz, C., Capron, E., Lipenkov, V., Loutre, M. F., Raynaud, D., Vinther, B., Svensson, A., Rasmussen, S. O., Severi, M., Blunier, T., Leuenberger, M., Fischer, H., Masson-Delmotte, V., Chappellaz, J., and Wolff, E.: An optimized multi-proxy, multi-site Antarctic ice and gas orbital chronology (AICC2012): 120-800 ka, Clim. Past, 9, 1715-1731, https://doi.org/10.5194/cp-9-1715-2013, 2013.

Blaauw, M.: Methods and code for "classical" age-modelling of radiocarbon sequences, Quat. Geochronol., 5, 512-518, 2010.

Blaauw, M. and Christen, J. A.: Flexible paleoclimate age-depth models using an autoregressive gamma process, International Society for Bayesian Analysis, 3, 457-474, 2011.

Bond, G. and Lotti, R.: Icebergs discharges into the North Atlantic on millenial time scales during the Last Glaciation, Science, 267, 1005-1009, 1995.

Burrows, M. T., Schoeman, D. S., Buckley, L. B., Moore, P. J., Poloczanska, E. S., Brander, K. M., Brown, C., Bruno, J. F., Duarte, C. M., Halpern, B. S., Holding, J., Kappel, C. V., Kiessling, W., O'Connor, M. I., Pandolfi, J. M., Parmesan, C., Schwing, F. B., Sydeman, W. J., and Richardson, A. J.: The pace of shifting climate in marine and terrestrial ecosystems, Science, 334, 652-655, 2011.

Burrows, M. T., Schoeman, D. S., Richardson, A. J., Garcia Molinos, J., Hoffmann, A., Buckley, L. B., Moore, P. J., Brown, C. J., Bruno, J. F., Duarte, C. M., Halpern, B. S., Hoegh-Guldberg, O., Kappel, C. V., Kiessling, W., O’Connor, M. I., Pandolfi, J. M., Parmesan, C., Sydeman, W. J., Ferrier, S., Williams, K. J., and Poloczanska, E. S.: Geographical limits to species-range shifts are suggested by climate velocity, Nature, 507, 492-495, 2014.

Cacho, I., Grimalt, J. O., Pelejero, C., Canals, M., Sierro, F. J., Flores, J. A., and Shackleton, N. J.: Dansgaard-Oeschger and Heinrich event imprints in Alboran Sea paleotemperatures, $\mathrm{Pa}$ leoceanography, 14, 698-705, 1999.

Capron, E., Landais, A., Chappellaz, J., Schilt, A., Buiron, D., Dahl-Jensen, D., Johnsen, S. J., Jouzel, J., Lemieux-Dudon, B., Loulergue, L., Leuenberger, M., Masson-Delmotte, V., Meyer, H., Oerter, H., and Stenni, B.: Millennial and sub-millennial scale climatic variations recorded in polar ice cores over the last glacial period, Clim. Past, 6, 345-365, https://doi.org/10.5194/cp-6345-2010, 2010. 
Chappellaz, J., Blunier, T., Kints, S., Dällenbach, A., Barnola, J.M., Schwander, J., Raynaud, D., and Stauffer, B.: Changes in the atmospheric $\mathrm{CH}_{4}$ gradient between Greenland and Antarctica during the Holocene, J. Geophys. Res., 102, 15987-15997, 1997.

Dansgaard, W., Johnsen, S., Clausen, H. B., Dahl-Jensen, D., Gundestrup, N., Hammer, C. U., and Oeschger, H.: North Atlantic climatic oscillations revealed by deep Greenland ice cores, in: Climate Processes and Climate Sensitivity, edited by: Hansen, J. E. and Takahashi, T., American Geophysical Union, Washington, 288-298, 1984.

de Beaulieu, J. L. and Reille, M.: A long upper Pleistocene pollen record from Les Echets, near Lyon, France, Boreas, 13, 111-132, 1984.

de Beaulieu, J.-L. and Reille, M.: The last climatic cycle at La Grande Pile (Vosges, France), a new pollen profile, Quaternary Sci. Rev., 11, 431-438, 1992.

Deino, A. L., Orsi, G., de Vita, S., and Piochi, M.: The age of the Neapolitan Yellow Tuff caldera-forming eruption (Campi Flegrei caldera - Italy) assessed by ${ }^{40} \mathrm{Ar} /{ }^{39} \mathrm{Ar}$ dating method, J. Volcanol. Geoth. Res., 133, 157-170, 2004.

Desprat, S., Diaz Fernandez, P. M., Coulon, T., Ezzat, L., J. Pessarossi-Langlois, Gil, L., Morales-Molino, C., and Sanchez Goñi, M. F.: Pinus nigra (European black pine) as the dominant species of the last glacial pinewoods in south-western to central Iberia: a morphological study of modern and fossil pollen, J. Biogeogr., 42, 1998-2009, 2015.

Faegri, K., Iversen, J., Kaland, P. E., and Krzywinski, K.: Textbook of Pollen Analysis, Wiley, Chichester, 1989.

Fletcher, W. J., Sanchez Goñi, M. F., Allen, J. R. M., Cheddadi, R., Combourieu Nebout, N., Huntley, B., Lawson, I., Londeix, L., Magri, D., Margari, V., Müller, U., Naughton, F., Novenko, E., Roucoux, K., and Tzedakis, P. C.: Millennial-scale variability during the last glacial in vegetation records from Europe, Quaternary Sci. Rev., 29, 2839-2864, 2010.

Flückiger, J., Blunier, T., Stauffer, B., Chappellaz, J., Spahni, R., K. Kawamura, Schwander, J., Stocker, T. F., and Dahl-Jensen, D.: $\mathrm{N}_{2} \mathrm{O}$ and $\mathrm{CH}_{4}$ variations during the last glacial epoch: insight into global processes, Global Biogeochem. Cy., 18, GB1020, https://doi.org/10.1029/2003GB002122, 2004.

Gosling, W. D., Bush, M. B., Hanselman, J. A., and ChepstowLusty, A.: Glacial-interglacial changes in moisture balance and the impact on vegetation in the Southern Hemisphere tropical Andes (Bolivia/Peru), Palaeogeogr. Palaeocl., 259, 35-50, 2008.

Grigg, L. D. and Whitlock, C.: Late-glacial vegetation and climate change in Western Oregon, Quaternary Res., 49, 287-298, 1998.

Hajdas, I.: Radiocarbon: calibration to absolute time scale, in: Treatise on Geochemistry, edited by: Turekian, K. and Holland, H., Elsevier, Oxford, 37-43, 2014.

Harrison, S. and Sánchez Goñi, M. F.: Global patterns of vegetation response to millennial-scale variability and rapid climate change during the last glacial period, Quaternary Sci. Rev., 29, $2957-$ 2980, 2010.

Haslett, J. and Parnell, A. C.: A simple monotone process with application to radiocarbon dated depth chronologies, J. Roy. Stat. Soc. C-APP., 57, 399-418, 2008.

Heinrich, H.: Origin and consequences of cyclic ice rafting in the northeast Atlantic ocean during the past 130,000 years, Quaternary Res., 29, 142-152, 1988.
Henderson, G. M. and Slowey, N. C.: Evidence from U-Th dating against Northern Hemisphere forcing of the penultimate deglaciation, Nature, 404, 61-66, 2000.

Hessler, I., Dupont, L., Bonnefille, R., Behling, H., González, C., Helmens, K. F., Hooghiemstra, H., Lebamba, J., Ledru, M.P., and Lézine, A.-M.: Millennial-scale changes in vegetation records from tropical Africa and South America during the last glacial, Quaternary Sci. Rev., 29, 2882-2899, 2010.

Heusser, C. J.: Palynology and phytogeographical significance of a late-Pleistocene refugium near Kalaloch, Washington, Quaternary Res., 2, 189-201, 1972.

Heusser, C. J.: Ice age vegetation and climate of subtropical Chile, Palaeogeogr. Palaeocl., 80, 107-127, 1990.

Heusser, L. E., Heusser, C. J., and Pisias, N.: Vegetation and climate dynamics of southern Chile during the past 50,000 years: results of ODP Site 1233 pollen analysis, Quaternary Sci. Rev., 25, 474 485, 2006.

Hogg, A. G., Hua, Q., Blackwell, P. G., Niu, M., Buck, C. E., Guilderson, T. P., Heaton, T. J., Palmer, J. G., Reimer, P. J., Reimer, R. W., Turney, C. S. M., Zimmerman, S. R. H.: SHCAL13 Southern Hemisphere calibration, 0-50,000 years cal BP, Radiocarbon, 55, 1889-1903, 2013.

Huber, C., Leuenberger, M., Spahni, R., Flückiger, J., Schwander, J., Stocker, T. F., Johnsen, S., Landais, A., and Jouzel, J.: Isotope calibrated Greenland temperature record over Marine Isotope Stage 3 and its relation to $\mathrm{CH}_{4}$, Earth Planet. Sc. Lett., 243, 504-519, 2006.

Jimenez-Moreno, G., Anderson, R. S., Desprat, S., Grigg, L. D., Grimm, E. C., Heusser, L. E., Jacobs, B. F., López-Martínez, C., Whitlock, C. L., and Willard, D. A.: Millennial-scale variability during the last glacial in vegetation records from North America, Quaternary Sci. Rev., 29, 2865-2881, 2010.

Johnsen, S. J., Clausen, H. B., Dansgaard, W., Fuhrer, K., Gundestrup, N., C. U. Hammer, Iversen, P., Jouzel, J., Stauffer, B., and Steffensen, J. P.: Irregular glacial interstadials in a new Greenland ice core, Nature, 359, 311-313, 1992.

Katoh, S., Handa, K., Hyodo, M., Sato, H., Nakamura, T., Yamashita, T., and Danhara, T.: Estimation of eruptive ages of the late Pleistocene tephra layers derived from Daisen and Sambe Volcanoes based on AMS $-{ }^{14} \mathrm{C}$ dating of the moor sediments at Ohnuma Moor in the Chugoku Mountains, Western Japan, Nature and Human Activities, 11, 29-50, 2007.

Landais, A., Masson-Delmotte, V., Jouzel, J., Raynaud, D., Johnsen, S., Huber, C., Leuenberger, M., Schwander, J., and Minster, B.: The glacial inception as recorded in the NorthGRIP Greenland ice core: timing, structure and associated abrupt temperature changes, Clim. Dynam., 26, 273-284, https://doi.org/10.1007/s00382-005-0063-y, 2005.

Laskar, J., Robutel, P., Joutel, F., Gastineau, M., Correia, A. C. M., and Levrard, B.: A long-term numerical solution for the insolation quantities of the Earth, A and A, 428, 261-285, 2004.

Levavasseur, G., Vrac, M., Roche, D. M., and Paillard, D.: Statistical modelling of a new global potential vegetation distribution, Environ. Res. Lett., 7, 044019, 2012.

Lézine, A.-M. and Denèfle, M.: Enhanced anticyclonic circulation in the eastern North Atlantic during cold intervals of the last deglaciation inferred from deep-sea pollen records, Geology, 25, 119-122, 1997. 
Liew, P.-M., Huang, S.-Y., and Kuo, C.-M.: Pollen stratigraphy, vegetation and environment of the last glacial and Holocenea record from Toushe Basin, central Taiwan, Quatern. Int., 147, 16-33, 2006.

Loarie, S. R., Duffy, P. B., Hamilton, H., Asner, G. P., Field, C. B., and Ackerly, D. D: The velocity of climate change, Nature, 462, 1052-1055, 2009.

Magri, D. and Sadori, L.: Late Pleistocene and Holocene pollen stratigraphy at Lago di Vico, central Italy, Veg. Hist. Archaeobot., 8, 247-260, 1999.

Margari, V., Gibbard, P. L., Bryant, C. L., and Tzedakis, P. C.: Character of vegetational and environmental changes in southern $\mathrm{Eu}-$ rope during the last glacial period; evidence from Lesvos Island, Greece, Quaternary Sci. Rev., 28, 1317-1339, 2009.

Martinson, D. G., Pisias, N. G., Hays, J. D., Imbrie, J., Moore, T. C., and Shackleton, N. J.: Age dating and orbital theory of the Ice Ages: development of a high-resolution 0 to 300,000 year chronostratigraphy, Quaternary Res., 27, 1-29, 1987.

Marzin, C. and Braconnot, P.: Variations of Indian and African monsoons induced by insolation changes at 6 and $9.5 \mathrm{kyr} \mathrm{BP}$, Clim. Dynam., 33, 215-231, 2009.

McManus, J. F., Bond, G. C., Broecker, W. S., Johnsen, S., Labeyrie, L., and Higgins, S.: High-resolution climate records from the North Atlantic during the last interglacial, Nature, 371, 326-329, 1994.

Moore, P. D., Webb, J. A., and Collinson, M. E.: Pollen Analysis, Blackwell, Oxford, 1991.

Nakagawa, T., Gotanda, K., Haraguchi, T., Danhara, T., Yonenobu, H., Brauer, A., Yokoyama, Y., Tada, R., Takemura, K., Staff, R. A., Payne, R., Bronk Ramsey, C., Bryant, C., Brock, F., Schlolaut, G., Marshall, M., Tarasov, P., and Lamb, H.: SG06, a fully continuous and varved sediment core from Lake Suigetsu, Japan: stratigraphy and potential for improving the radiocarbon calibration model and understanding of late Quaternary climate changes, Quaternary Sci. Rev., 36, 164-176, 2012.

Newnham, R. M., Eden, D. N., Lowe, D. J., and Hendy, C. H.: Rerewhakaaitu Tephra, a land-sea marker for the last termination in New Zealand, with implications for global climate change, Quaternary Sci. Rev., 22, 289-308, 2003.

Ordoñez, A. and Williams, J. W.: Climatic and biotic velocities for woody taxa distributions over the last 16000 years in eastern North America, Ecol. Lett., 16, 773-781, 2013.

Parnell, A. C., Haslett, J., Allen, J. R. M., Buck, C. E., and Huntley, B.: A new approach to assessing synchroneity of past events using Bayesian reconstructions of sedimentation history, Quaternary Sci. Rev., 27, 1872-1885, 2008.

Prentice, I. C.: Records of vegetation in time and space: the principles of pollen analysis, in: Vegetation History, edited by: Huntley, B. and Webb III, T., Kluwer, Dordrecht, 17-42, 1988.

Reille, M., Andrieu, V., de Beaulieu, J.-L., Guenet, P., and Goeury, C.: A long pollen record from Lac du Bouchet, Massif Central, France: for the period ca. 325 to $100 \mathrm{kaBP}$ (OIS 9c to OIS 5e), Quaternary Sci. Rev., 17, 1107-1123, 1998.

Reimer, P. J., Bard, E., Bayliss, A., Beck, J. W., Blackwell, P. G., Bronk Ramsey, C., Buck, C. E., Cheng, H., Edwards, R. L., and Friedrich, M.: IntCal13 and Marine13 radiocarbon age calibration curves 0-50,000 years cal BP, 2013.
Sánchez Goñi, M. F.: Introduction to climate and vegetation in Europe during MIS 5, in: The Climate of Past Interglacials, edited by:. Sirocko, F., Claussen, M., Sánchez Goñi, M. F., and Litt, T., Elsevier, Amsterdam, 197-205, 2007.

Sánchez Goñi, M. F., Eynaud, F., Turon, J.-L., and Shackleton, N. J.: High resolution palynological record off the Iberian margin: direct land-sea correlation for the Last Interglacial complex, Earth Planet. Sc. Lett., 171, 123-137, 1999.

Sánchez Goñi, M. F., Turon, J.-L., Eynaud, F., and Gendreau, S.: European climatic response to millenial-scale climatic changes in the atmosphere-ocean system during the Last Glacial period, Quaternary Res., 54, 394-403, 2000.

Sánchez Goñi, M. F., Landais, A., Fletcher, W. J., Naughton, F., Desprat, S., and Duprat, J.: Contrasting impacts of DansgaardOeschger events over a western European latitudinal transect modulated by orbital parameters, Quaternary Sci. Rev., 27, 1136-1151, 2008.

Sánchez Goñi, M. F., Bard, E., Landais, A., Rossignol, L., and d'Errico, F.: Air-sea temperature decoupling in western Europe during the last interglacial-glacial transition, Nat. Geosci., 6, 837-841, 2013.

Sánchez Goñi, M. F. et al.: The ACER pollen and charcoal database: a global resource to document vegetation and fire response to abrupt climate changes during the last glacial period, available at: https://doi.org/10.1594/PANGAEA.870867, 2017.

Sawada, K., Arita, Y., Nakamura, T., Akiyama, M., Kamei, T., and Nakai, N.: ${ }^{14} \mathrm{C}$ dating of the Nojiri-ko Formation using accelerator mass spectrometry, Earth Sci., 46, 133-142, 1992.

Shackleton, N. J., Hall, M. A., and Vincent, E.: Phase relationships between millenial scale events $64000-24000$ years ago, Paleoceanography, 15, 565-569, 2000.

Shackleton, N. J., Fairbanks, R. G., Chiu, T., and Parrenin, F.: Absolute calibration of the Greenland time scale: implications for Antarctic time scales and for $\Delta^{14} \mathrm{C}$, Quaternary Sci. Rev., 23, 1513-1523, 2004.

Shane, P., Smith, V. C., Lowe, D. J., and Nairn, I.: Re-identification of c. 15700 cal yr BP tephra bed at Kaipo Bog, eastern North Island: implications for dispersal of Rotorua and Puketarata tephra beds, New Zeal. J. Geol. Geop., 46, 591-596, 2003.

Smith, V. C., Mark, D. F., Staff, R. A., Blockley, S. P. E., Ramsey, C. B., Bryant, C. L., Nakagawa, T., Han, K. K., Weh, A., Takemura, K., and Danhara, T.: Toward establishing precise ${ }^{40} \mathrm{Ar} /{ }^{39} \mathrm{Ar}$ chronologies for Late Pleistocene palaeoclimate archives: an example from the Lake Suigetsu (Japan) sedimentary record, Quaternary Sci. Rev., 30, 2845-2850, 2011.

Smith, V. C., Staff, R. A., Blockley, S. P. E., Bronk Ramsey, C., Nakagawa, T., Mark, D. F., Takemura, K., and Danhara, T.: Identification and correlation of visible tephras in the Lake Suigetsu SG06 sedimentary archive, Japan: chronostratigraphic markers for synchronising of east Asian/west Pacific palaeoclimatic records across the last $150 \mathrm{ka}$, Quaternary Sci. Rev., 67, 121-137, 2013.

Steffensen, J. P., Andersen, K. K., Bigler, M., Clausen, H. B., Dahl-Jensen, D., Fischer, H., Goto-Azuma, K., Hansson, M., Johnsen, S. J., Jouzel, J., Masson-Delmotte, V., Popp, T., Rasmussen, S. O., Röthlisberger, R., Ruth, U., Stauffer, B., SiggaardAndersen, M.-L., Sveinbjörnsdóttir, A.-E., Svensson, A., and White, J. W. C.: High-resolution Greenland ice coredata show 
abrupt climate change happens in few years, Nature, 321, 680684, 2008.

Svensson, A., Andersen, K. K., Bigler, B., Clausen, H. B., DahlJensen, D., Davies, S. M., Johnsen, S. J., Muscheler, R., Rasmussen, S. O., Röthlisberger, R., Steffensen, J. P., and Vinther, B. M.: The Greenland ice core chronology 2005, 15$42 \mathrm{ka}$, Part 2: comparison to other records, Quaternary Sci. Rev., 25, 3258-3267, 2006.

Svensson, A., Andersen, K. K., Bigler, M., Clausen, H. B., DahlJensen, D., Davies, S. M., Johnsen, S. J., Muscheler, R., Parrenin, F., Rasmussen, S. O., Röthlisberger, R., Seierstad, I., Steffensen, J. P., and Vinther, B. M.: A 60000 year Greenland stratigraphic ice core chronology, Clim. Past, 4, 47-57, https://doi.org/10.5194/cp-4-47-2008, 2008.

Takahara, H., Igarashi, Y., Hayashi, R., Kumon, F., Liew, P.-M., Yamamoto, M., Kawai, S., Oba, T., and Irino, T.: Millennial-scale variability in vegetation records from the East Asian Islands: Taiwan, Japan and Sakhalin, Quaternary Sci. Rev., 29, 2900-2917, 2010.

R Development Core Team, R: A language and environment for statistical computing, in: R Foundation for Statistical Computing, Vienna, Austria, 2016.

Tzedakis, P. C., Pälike, H., Roucoux, K. H., and de Abreu, L.: Atmospheric methane, southern European vegetation and low-mid latitude links on orbital and millennial timescales, Earth Planet. Sc. Lett., 277, 307-317, 2009.
Vandergoes, M. J., Hogg, A. G., Lowe, D. J., Newnham, R. M., Denton, G. H., Southon, J. R., Barrell, D. J. A., Wilson, C. J. N., McGlone, M. S., Allan, A. S. R., Almond, P. C., Petchey, F., Dabell, K., Dieffenbacher-Krall, A. C., and Blaauw, M.: A revised age for the Kawakawa/Oruanui tephra, a key marker for the Last Glacial Maximum in New Zealand, Quaternary Sci. Rev., 74, 195-201, 2013.

Wang, Y. J., Cheng, H., Edwards, R. L., An, Z. S., Wu, J. Y., Shen, C.-C., and Dorale, J. A.: A high-resolution absolute-dated Late Pleistocene monsoon record from Hulu Cave, China, Science, 294, 2345-2348, https://doi.org/10.1126/science.1064618, 2001.

Weirauch, D., Billups, K., and Martin, P.: Evolution of millennial-scale climate variability during the mid-Pleistocene, Paleoceanography, 23, PA3216, https://doi.org/10.1029/2007PA001584, 2008.

Whitlock, C., Sarna-Wojcicki, A. M., Bartlein, P. J., and Nickmann, R. J.: Environmental history and tephrostratigraphy at Carp Lake, southwestern Columbia Basin, Washington, USA, Palaeogeogr. Palaeocl., 155, 7-29, 2000.

Wolff, E. W., Chappellaz, J., Blunier, T., Rasmussen, S. O., and Svensson, A. C.: Millennial-scale variability during the last glacial: the ice core record, Quaternary Sci. Rev., 29, 2828-2838, 2010.

Wulf, S., Kraml, M., Brauer, A., Keller, J., and Negendan, J. F. W.: Tephrochronology of the $100 \mathrm{ka}$ lacustrine sediment record of Lago Grande di Monticchio (southern Italy), Quatern. Int., 122, 7-30, 2004. 